\title{
ASSENTAMENTOS IRREGULARES EM CURITIBA/PR:A PROTEÇÃO AO MEIO AMBIENTE E OS ENTRAVES PARAA REGULARIZAÇÃO DE MORADIAS
}

Miriam Olivia Knopik Ferraz Mestranda em Direito pela PUC/PR (Bolsista CAPES) e Graduada em Direito pela PUC/PR.
Pós-graduanda em Direito Constitucional pela Academia Brasileira de Direito Constitucional.
Secretária Executiva da Revista de Direito Econômico e Socioambiental da PUCPR. Email: m.okf@hotmail.com

\author{
Amanda Luiza da Silva Oliveira Pinto \\ Mestranda em Direito Econômico e Socioambiental pela PUC/PR. Membro do Núcleo de \\ Pesquisas em Políticas Públicas e Desenvolvimento Humano, do Núcleo de Estudos de Pes- \\ quisas em Tributação, Complexidade e Desenvolvimento e do Núcleo de Estado e Iniciativa \\ Privada na Otimização Sustentável da Infraestrutura. Advogada. \\ E-mail: amandaluiza@oliveirapinto.com.br \\ Luiz Alberto Blanchet \\ Doutor e Mestre em Direito pela Universidade Federal do Paraná - UFPR (1997/1991). Possui \\ graduação em Direito pela Pontifícia Universidade Católica do Paraná (1975). Atualmente \\ é Professor do Programa de Pós-Graduação da Pontifícia Universidade Católica do Paraná \\ (PPGD/PUC/PR) e Membro Catedrático da Academia \\ Brasileira de Direito Constitucional (ABDConst) \\ Email: blanchet@blanchet.adv.br
}

\section{RESUMO}

Os problemas que envolvem assentamentos irregulares estão associados a uma multiplicidade de direitos reconhecidos tanto no âmbito internacional como nacional, e sua integração reflete a sociedade complexa que se vivencia. Ao adentrar no regime jurídico de planejamento urbano de Curitiba/PR, busca-se estudar a relação que existe na normativa entre a moradia digna e a proteção ao meio ambiente. Transpassando este estudo teórico, adentra-se nos problemas atuais atrelados aos assentamentos irregulares e especialmente os que estão em áreas de preservação ambiental e permanente dentro da cidade de Curitiba/PR, desmistificando diversos sensos comuns. Por fim, estudam-se a fiscalização, o diálogo e a integração entre as políticas públicas habitacionais e ambientais como possíveis caminhos para a superação dos problemas. A metodologia utilizada é a lógico-dedutiva, por meio do estudo aprofundado das legislações, e a comparativa, através da apresentação de diversos dados, depoimentos e enfoque nas diversas fontes para a construção do conhecimento acadêmico.

PALAVRAS-CHAVE: Assentamentos Irregulares; Proteção ao Meio Ambiente; Planejamento; Curitiba/PR. 
IRREGULAR NESTINGS IN CURITIBA/PR: ENVIRONMENTAL

PROTECTION AND THE HINDRANCES FOR THE

REGULARIZATION OF HOUSING

\begin{abstract}
The problems involving irregular settlements are associated with a multiplicity of rights recognized both internationally and nationally, and their integration reflects the complex society that is experienced. When entering the legal regime of urban planning of Curitiba/PR seeks to study the relationship that exists in the norm between decent housing and protection of the environment. Crossing this theoretical study, it is introduced in the current problems related to the irregular settlements and especially those that are in Environmental and Permanent Preservation Areas within the city of Curitiba/PR demystifying several common senses. Finally, we study surveillance, dialogue and integration between public housing and environmental policies as possible ways to overcome the problems. The methodology used is the logical deductive by means of the in-depth study of the legislations and the comparative one by means of the presentation of diverse data, testimonials and the focus in the diverse sources for the construction of the academic knowledge.
\end{abstract}

KEYWORDS: Irregular settlements; Protection of the environment; planning; Curitiba/PR. 


\section{INTRODUÇÃO}

Os assentamentos irregulares são fenômenos que ocorrem em diversas cidades por todo o globo e, ao contrário do que diz o senso comum, Curitiba também os possui, desde a sua formação. Entender os assentamentos irregulares é também entender a formação de cidades reais e toda a complexidade de direitos que envolvem os moradores e a situação em que vivem. Paralelamente a isso, é perceptível o grande alcance que essas situações possuem e, como objeto desse estudo, busca-se analisar o ponto de convergência entre os assentamentos irregulares e o meio ambiente.A legislação, de certa forma, alcançou esta linha limítrofe, mas é através da consonância da normativa e do estudo das vivências reais que estudar-se-á a realidade das ocupações irregulares em áreas de preservação ambiental e permanente.

Por fim, as inspirações pensadas com o objetivo de reduzir e sanar essas adversidades não podem ser construídas somente por meio de leis esparsas e inaplicadas, e sim, através de um diálogo construtivo entre Poder Público, sociedade civil, movimentos e associações. Como se evidenciará neste estudo, é através da consonância entre políticas habitacionais e ambientais que se iniciará a construção destas soluções.

Dessa forma, o presente trabalho se desenvolve primeiramente através da análise do regimejurídico envolvente tanto no nível constitucional, federal como municipal; posteriormente, adentra-se nos atuais programas do município de Curitiba/PR que ensejam efetivamente influência na questão habitacional e ambiental. Após o cotejo teórico, adentra-se nas principais questões elencadas pela sociedade, pelas estatísticas e gráficos pesquisados dos problemas que aqueles dois parâmetros na realidade ensejam. Por fim, buscar-se-á a inspiração para futuras soluções através de uma análise estritamente jurídica da situação, propondo a fiscalização, o diálogo e a construção de políticas habitacionais e ambientais, de forma integrada, para a formação de uma sociedade digna e ambientalmente responsável.

\section{REGIME JURÍDICO NACIONAL RELACIONADO À QUESTÃo DA MORADIA E MEIO AMBIENTE}

Ao se pensar em todos os problemas que envolvem os assentamentos irregulares, é necessário ter em mente que estes abrangem 
uma multiplicidade de direitos como o direito à moradia, o direito à cidade e ao planejamento urbano, o direito ao meio ambiente equilibrado; e os indiretos, como a própria dignidade da pessoa humana. Tais direitos se interligam, e devem ser tratados dessa forma, principalmente quando se busca uma solução e a própria fundamentação legal para a regulamentação da expansão da cidade de forma digna.

Em um primeiro momento, o direito à moradia está regulamentado no Direito internacional e nacional, começando pela Declaração Universal dos Direitos Humanos da Organização das Nações Unidas (ONU) de 1948, que coloca a habitação como um dos requisitos necessários para que a pessoa tenha um padrão de vida adequado ${ }^{1}$, posteriormente seguido por diversos outros tratados internacionais. ${ }^{2} \mathrm{Na}$ legislação interna brasileira, tem-se este direito presente na Constituição, no art. $6^{\circ}$ e ainda, a garantia da sua aplicabilidade imediata, conforme o art. $5^{\circ}, \S 1^{\circ}$ desta Carta. ${ }^{3}$ Em outros âmbitos, este direito está pulverizado em diversas legislações e institutos como: o Estatuto da Cidade (Lei 10.257/01); o Ministério das Cidades; a Política Nacional de Desenvolvimento Urbano; o Sistema Nacional de Habitação de Interesse Social (criado pela Lei 11.124/05 e que resultou na criação do Fundo Nacional de Habitação de Interesse Social e o Conselho Gestor deste fundo) e o Programa Minha Casa Minha Vida presente na Lei 11.977/09. Entretanto, apesar da grande fundamentação legal nacional e internacional, a definição da composição do direito à moradia ainda enseja grandes discussões na doutrina. ${ }^{4}$

Paralelamente, o urbanismo também mereceu destaque na Constituição de 1988, que incluiu um capítulo específico para regulá-lo

1 Artigo XXV: 1. Toda pessoa tem direito a um padrão de vida capaz de assegurar a si e a sua família saúde e bem- estar, inclusive alimentação, vestuário, habitação [...]. ONU. Declaração Universal dos Direitos Humanos, 1948. Disponível em: <http://portal.mj.gov.br/sedh/ct/legis_intern/ddh_bib_inter_universal.htm>. Acesso em 25 de novembro de 2017.

2 Como por exemplo: Pacto Internacional sobre Direitos Civis e Políticos (Nova York, 1966); o Pacto Internacional sobre Direitos Econômicos, Sociais e Culturais (Nova York, 1966); a Convenção Internacional sobre a Eliminação de Todas as Formas de Discriminação Racial (Nova York, 1965); a Convenção sobre a Eliminação de Todas as Formas de Discriminação contra a Mulher (Nova York, 1979); a Convenção Internacional sobre os Direitos da Criança (Nova York,1989); e a Convenção Relativa ao Estatuto dos Refugiados (Genebra, 1951). Sobre a temática consulte: ALVES, Carolina Caraíba Nazareth. Direito à moradia: análise da situação no município de Curitiba à luz de indicadores sociais. Dissertação (Mestrado em Direito das Relações Sociais) - Programa de Pós-Graduação em Direito da Universidade Federal do Paraná, Curitiba, 2010, p.25.

3 Sobre a regulamentação jurídica completa do direito fundamental a moradia, consulte: GOMES, Francisco Donizete. Direito fundamental social à moradia: legislação internacional, estrutura constitucional e plano infraconstitucional. Porto Alegre: UFRGS. Faculdade de Direito 2005.

4 SARLET, Ingo Wolfgang. O Direito Fundamental à Moradia na Constituição: Algumas Anotações a Respeito de seu Contexto, Conteúdo e Possível Eficácia. Revista Brasileira de Direito PúblicoRBDP, Belo Horizonte, ano 1, n.02, p. 65-119, jul./set. 2003. 
dentro do título da ordem econômica e financeira; esta inclusão se deu através de uma proposta popular, o que revela o grande clamor popular em que esses direitos estão calcados. ${ }^{5} \mathrm{O}$ próprio desenvolvimento do espaço urbano contemporâneo possui como base tanto no âmbito internacional,quanto no âmbito interno,o Direito à Cidade. Entretanto,este direito não possui uma conceituação única mas, sim, está em constante transformação. ${ }^{6}$ David Harvey afirma que "reivindicar o direito à cidade" equivaleria a reivindicar um poder sobre os processos de urbanização,ou seja,"sobre o modo como nossas cidades são feitas e refeitas". ${ }^{7} \mathrm{O}$ direito à cidade seria, então, o direito de transformar a cidade "de acordo com as necessidades de todos e não de alguns grupos específicos". 8

A Constituição Federal de 1988 superou a concepção civilista da propriedade, que se mostrava com o enfoque individualista, para uma concepção voltada ao núcleo da função da propriedade. ${ }^{9}$ Dessa forma, segundo Orlando Alves dos Santos Junior e Cristiano Müller, o direito à cidade é "interdependente a todos os direitos humanos internacionalmente reconhecidos" e, assim, são concebidos com o objetivo de incluir vários direitos como direitos civis, políticos, econômicos, sociais, culturais e ambientais, dentre outros. ${ }^{10}$

Posteriormente, a aprovação do Estatuto da Cidade, Lei n ${ }^{\circ} 10.257$ de 2001, trouxe como principal característica a competência municipal sobre a matéria de planejamento. Assim, visa assegurar um planejamento apropriado das políticas urbanas, com o objetivo de garantir que se observe uma gestão eficiente da cidade, dispondo ainda de instrumentos para a

\footnotetext{
5 "Uma Emenda Popular da Reforma Urbana consolidou as reivindicações, propostas e instrumentos urbanísticos que se pretendia contemplar na Nova Carta, a fim de intervir no caos social em que haviam se transformado as cidades brasileiras". ALFONSIN, Betânia de Moraes. Da Invisibilidade à Regularização Fundiária: a trajetória legal da moradia de baixa renda em Porto Alegre. In: FERNANDES, Edésio; ALFONSIN, Betânia de Moraes (Coord. E co-autores). A lei e a ilegalidade na produção do espaço urbano. Belo Horizonte: Del Rey, 2003, p.168.

6 SANCHES, Jussara Romero Sanches; ARAUJO JUNIOR, Miguel Etinger de. Multidimensionalidade do direito à cidade no estatuto da cidade. Revista de Direito Urbanístico, Cidade e Alteridade. e-ISSN: 2525-989X. Brasília, v. 3, n. 1, Jan/Jun. 2017, p.1.

7 HARVEY, David. A liberdade da cidade. In: MARICATO, Ermínia [et al.]. Cidades rebeldes: passe livre e as manifestações que tomaram as ruas do Brasil. São Paulo: Boitempo: Carta Maior, 2013, p.30

8 SANCHES, Jussara Romero Sanches; ARAUJO JUNIOR, Miguel Etinger de. Multidimensionalidade... Op. Cit.p.4.

9 FERNANDES, Edésio. Do código civil ao estatuto da cidade: algumas notas sobre a trajetória do direito urbanístico no Brasil. In: FERNANDES, Edésio; ALFONSIN, Betânia. Evolução do direito urbanístico brasileiro. Belo Horizonte: PUC Minas Virtual, 2006, p.38.

10 SANTOS JUNIOR, Orlando Alves dos; MÜLLER, Cristiano (orgs.). Direito Humano à Cidade. Coleção Cartilhas de Direitos Humanos, vol. VI, $1^{\text {a }}$ ed., Curitiba: Plataforma DhescaBrasil, 2008, p.31.
} 
concretização do desenvolvimento sustentável do meio ambiente urbano. ${ }^{11}$ Outras iniciativas contribuíram para o fortalecimento desse direito, como a criação do Ministério das Cidades em 2003; as conferências nacionais, estaduais e municipais das cidades; o Conselho Nacional das Cidades; os programas federais urbanos, como o Programa de Aceleração do Crescimento (PAC) e, assim como para o direito à moradia, o Programa Minha Casa Minha Vida. ${ }^{12}$

O Plano Diretor, referido na Constituição, no art.182 e previsto na lei 10.257/2001, adentra na competência municipal e se transforma em um dos principais instrumentos da política de desenvolvimento e expansão urbana, e busca garantir o planejamento da atuação do Poder Público, possibilitando a gestão ordenada das cidades, aliando a atuação do Poder Público e a participação da sociedade civil, no direcionamento das ações estatais, objetivando o bem-estar dos indivíduos. O plano diretor irá nortear a atuação do planejamento de cada cidade, e assim, sofrerá adaptações sazonais. ${ }^{13}$

Como se observa dos dispositivos legais citados,pensar o planejamento e o desenvolvimento de cidades não pode ser desatrelado de toda a questão ambiental que envolve as moradias e vivências urbanas. Além disso, trata-se de um próprio diálogo dos artigos presentes na Constituição e o cumprimento de seus objetivos de forma interligada. Fato que se pode observar no art. 225 da Constituição Federal, o qual assegura que todos têm direito ao meio ambiente equilibrado, sendo dever do Poder Público e da coletividade defendê-lo e preservá-lo, com o objetivo de garantir qualidade de vida para as presentes e futuras gerações. A interligação com outros elementos da Constituição está presente na análise multidimensional da relação entre o ser humano e o meio ambiente ${ }^{14}$ e também no fato de que, para a realização desses objetivos, é preciso que o Poder Público planeje suas ações.

Assim, o meio ambiente urbano necessita de ações globais e normas específicas que objetivam a formação de uma vida digna a todos os indivíduos, em consonância com o disposto nos arts.182 e 183, do texto

11 FERNANDES, Edésio.Do código civil ao estatuto da cidade... Op Cit. p.38.

12 FERNANDES, Edésio. Estatuto da Cidade, mais de 10 anos depois: razão de descrença, ou razão de otimismo. Revista UFMG. Belo Horizonte, vol. 20, n. 1, jan./jul., 2013, p. 212-233.

13 SILVA, Poliana Henriques da. O impacto do plano diretor do município de Volta Redonda na busca de uma sociedade cidadã. Revista de Direito Urbanístico, Cidade e Alteridade, e-ISSN: 2525-989X, Curitiba, v. 2, n. 2, Jul/Dez. 2016, p.168.

14 KALIL, Ana Paula Maciel Costa; FERREIRA, HelineSivini. A dimensão socioambiental do estado de direito. Veredas do Direito, Belo Horizonte, v.14. n.28. p.329-359. Janeiro/Abril de 2017. P.333 
constitucional, que dispõem sobre a política de desenvolvimento urbano, e novamente ao Estatuto da cidade e ao plano diretor.

\section{ASSENTAMENTOS IRREGULARES EM CURITIBA/PR E A DEGRADAÇÃO DO MEIO AMBIENTE: A TEORIA.}

Cabe, neste momento, traçar quais as legislações e projetos que atualmente estão em vigor em Curitiba/PR, no âmbito municipal, já que a análise da Constituição e da legislação federal já foi realizada, no que tange a políticas habitacionais e ambientais relacionadas,subdividida essa análise em três momentos: i) Plano Diretor; ii) Legislações Municipais esparsas;ii) Programas.

i) O Plano Diretor atual de Curitiba traz algumas disposições sobre a temática, as quais norteiam a atuação municipal. No art. 17, referente à estruturação urbana,encontram-se como diretrizes dessa política: a regularização de “assentamentos de interesse social já consolidados, incorporando-os à estrutura urbana, respeitado o interesse público" ${ }^{15}, \mathrm{e}$ "incentivar e promover ações para regularização das construções civis irregulares". ${ }^{16}$ Tem-se ainda a sessão III, que diz respeito à regularização fundiária simplificada, entretanto, restrita a imóveis de porte comercial. ${ }^{17} \mathrm{Em}$ paralelo a estas disposições, tem-se a determinação do art.62 do referido plano, em seu inciso XX:“estabelecer normas, padrões, restrições e incentivos ao uso e ocupação dos imóveis públicos e privados considerando os aspectos do meio ambiente natural, cultural e edificado visando à sustentabilidade ambiental". No Capítulo V, há a garantia de que deve ser assegurada a integração da política de habitação com as demais políticas públicas,“em especial as de desenvolvimento urbano e regional". ${ }^{18}$ Dessa forma, vê-se refletida a intenção constitucional do planejamento com a proteção e integração ambiental.

Há ainda a sessão específica sobre habitação de interesse social, que garante, no art. 79: 1. Os objetivos da referida política pública em parceria com a iniciativa privada; 2. Priorização da população de até 3 salários mínimos. 3. Como diretrizes gerais,aponta a promoção da

15 BRASIL, Plano Diretor de Curitiba. Lei Municipal nº 14.771/2015. Art. 17, XII. Disponível em: $<$ http://www.ippuc.org.br/visualizar.php?doc=http://admsite2013.ippuc.org.br/arquivos/documentos/D310/D310_001_BR.pdf> Acesso em 20 de dezembro de 2017.

16 BRASIL, Plano Diretor de Curitiba. Lei Municipal no ${ }^{\circ}$ 14.771/2015.... Op Cit.Art. 17, XV.

17 BRASIL, Plano Diretor de Curitiba. Lei Municipal no. 14.771/2015. ... Op Cit.Art. 34.

18 BRASIL, Plano Diretor de Curitiba. Lei Municipal no. 14.771/2015. ... Op Cit.Art. 78, IV. 
regularização, produção de moradias, ampliação do Fundo Municipal de Habitação de Interesse Social, diversificação de formas de acesso à habitação, e a promoção de estudos e projetos de aluguel social para ampliar o acesso à moradia a outros nichos populacionais como estudantes, idosos e jovens, sempre priorizando a população de baixa renda. ${ }^{19}$

Na sessão específica sobre a regularização fundiária, no art. 89, há a priorização da "permanência da população na área ocupada, assegurando o nível adequado de condições urbanísticas, sociais e ambientais, tais como salubridade, estabilidade, segurança, infraestrutura e acesso a serviços públicos". Ademais, não haverá esta permanência quando houver "situação de risco comprovado para as famílias,bem como por questões ambientais e urbanísticas irreversíveis" ${ }^{20}$. Além disso, há a disposição de que o município irá "promover medidas para prevenção, mediação e solução de conflitos fundiários coletivos" e voltando a sua atuação para o estabelecimento do menor custo possível, inclusive buscando a possibilidade da total gratuidade do processo. ${ }^{21}$

ii) Trabalhando em conjunto com o Plano Diretor, há diversas legislações municipais que tratam sobre a temática estudada a se citar de forma sintetizada:

a) Lei Municipal n ${ }^{\circ} 7833 / 1991$, que trata sobre a política de proteção, conservação e recuperação do meio ambiente, área ou Setores Especiais de Fundos de Vale e “determina as dimensões das faixas não edificáveis de drenagem de acordo com a área contribuinte da bacia hidrográfica"22; b)Lei Municipal n 9460/1998, que trata sobre a regularização de parcelamentos do solo para fins urbanos,os quais foram ,implantados irregularmente no município, no período de tempo até a data de 31 de dezembro de $1993^{23}$; c) Lei Municipal nº 9800/2000, que trata sobre o zoneamento, uso e ocupação do solo, incluindo a lei de zoneamento, o Setor Especial de Habitação de Interesse Social - SEHIS. Esta compreende as áreas onde há interesse público em ordenar a ocupação(urbanização ou regularização fundiária),implantar ou complementar

19 BRASIL, Plano Diretor de Curitiba. Lei Municipal no . 14.771/2015. ... Op Cit.Art. 79.

20 BRASIL, Plano Diretor de Curitiba. Lei Municipal $n^{0}$. 14.771/2015.... Op Cit.Art. 89.

21 BRASIL, Plano Diretor de Curitiba. Lei Municipal no . 14.771/2015. ... Op Cit.Art. 89.

22 BRASIL, Lei Municipal de Curitiba n⿳07833/1991. Disponível em: $<$ http://legisladocexterno.curitiba.pr.gov.br/AtosConsultaExternaDownload.aspx?Id=25486\&tipo=ass $>$. Acesso em 27 de dezembro de 2017.

23 BRASIL, Lei Municipal de Curitiba n0460/1998. Disponível em: <https://leismunicipais.com. br/a/pr/c/curitiba/lei-ordinaria/1998/946/9460/lei-ordinaria-n-9460-1998-dispoe-sobre-a-regularizacao-de-parcelamentos-do-solo-para-fins-urbanos-implantados-irregularmente-no-municipio-de-curitiba-ate-a-data-de-31-de-dezembro-de-1993-e-da-outras-providencias?q=9460>. Acesso em 27 de dezembro de 2017. 
programas habitacionais de interesse social24; d) Lei $\mathrm{n}^{\circ} 9802 / 2000$, que institui incentivos para a implantação de Programas Habitacionais de Interesse Social25; e) Lei n ${ }^{\circ} 9803 / 2000$, que autoriza o poder público municipal a conceder a transferência de potencial construtivo como forma de indenização nas desapropriações de áreas destinadas a programas habitacionais de interesse social $^{26}$;f) Lei ${ }^{\circ}$ 9804/2000, que cria o sistema de Unidades de Conservação do Município de Curitiba e estabelece critérios e procedimentos para implantação de novas Unidades de Conservação ${ }^{27} ; \mathrm{g}$ ) Lei $n^{\circ}$ 9805/2000, que cria o Setor Especial do Anel de Conservação Sanitário Ambiental28; h)Lei n ${ }^{\circ}$ 9806/2000, que institui o Código Florestal do Município de Curitiba $^{29}$; i) Decreto $n^{\text {o }} 196 / 2000$, que regulamenta a Lei $n^{\circ} 9.802 / 2000$,instituiu incentivos para a Implantação de Programas Habitacionais de Interesse ${ }^{30}$; j)Decreto $n^{0}$ 250/2000, que trata sobre a criação de novos Setores Especiais de Habitação de Interesse Social (SEHIS), sendo estes setoresáreas destinadas à implantação, pela COHAB-CT, os novos núcleos habitacionais de interesse social, sejam eles lotes, habitações unifamiliares, habitações coletivas ou mais de uma dessas modalidades, localizados em todos os zoneamentos, exceto: zonas industriais, zonas de serviço e áreas de proteção ambiental. ${ }^{31}$; k) Decreto ${ }^{0}$ 1164/2007, que institui a Comissão de Análise e Aprovação de Loteamentos de Interesse Social - CAALIS, órgão que

24 BRASIL, Lei Municipal de Curitiba n 9800/2000. Disponível em: < https://leismunicipais.com. br/plano-de-zoneamento-uso-e-ocupacao-do-solo-curitiba-pr>. Acesso em 27 de dezembro de 2017.

25 BRASIL, Lei Municipal de Curitiba n 9802/2000. Disponível em: <https://leismunicipais.com. br/a/pr/c/curitiba/lei-ordinaria/2000/981/9802/lei-ordinaria-n-9802-2000-institui-incentivos-para-aimplantacao-de-programas-habitacionais-de-interesse-social-e-revoga-a-lei-n-7841-91>. Acesso em 27 de dezembro de 2017.

26 BRASIL, Lei Municipal de Curitiba n 9803/2000. Disponível em: < https://leismunicipais.com. br/a/pr/c/curitiba/lei-ordinaria/2000/980/9803/lei-ordinaria-n-9803-2000-dispoe-sobre-a-transferencia-de-potencial-construtivo>. Acesso em 27 de dezembro de 2017.

27 BRASIL, Lei Municipal de Curitiba n 9804/2000. Disponível em: < https://leismunicipais.com. br/a/pr/c/curitiba/lei-ordinaria/2000/980/9804/lei-ordinaria-n-9804-2000-cria-o-sistema-de-unidadesde-conservacao-do-municipio-de-curitiba-e-estabelece-criterios-e-procedimentos-para-implantacaode-novas-unidades-de-conservacao $>$. Acesso em 27 de dezembro de 2017.

28 BRASIL, Lei Municipal de Curitiba n 9805/2000. Disponível em: < https://leismunicipais.com. br/a/pr/c/curitiba/lei-ordinaria/2000/980/9805/lei-ordinaria-n-9805-2000-cria-o-setor-especial-doanel-de-conservacao-sanitario-ambiental-e-da-outras-providencias $>$. Acesso em 27 de dezembro de 2017.

29 BRASIL, Lei Municipal de Curitiba n 9806/2000. Disponível em: < https://leismunicipais.com. br/a/pr/c/curitiba/lei-ordinaria/2000/980/9806/lei-ordinaria-n-9806-2000-institui-o-codigo-florestaldo-municipio-de-curitiba-revoga-as-leis-n-8353-93-e-8436-94-e-da-outras-providencias $>$. Acesso em 27 de dezembro de 2017.

30 BRASIL, Decreto Municipal de Curitiba no 196/2000. Disponível em: < https://eismunicipais. com.br/a/pr/c/curitiba/decreto/2000/19/196/decreto-n-196-2000-regulamenta-a-lei-n-9802-00-queinstituiu-incentivos-para-implantacao-de-programas-habitacionais-de-interesse-social-e-da-outrasprovidencias>. Acesso em 27 de dezembro de 2017.

31 BRASIL, Decreto Municipal de Curitiba no 250/2000. Disponível em: <https://leismunicipais.com.br/a/pr/c/curitiba/decreto/2000/25/250/decreto-n-250-2000-dispoe-sobre-a-criacao-denovos-setores-especiais-de-habitacao-de-interesse-social>. Acesso em 27 de dezembro de 2017. 
possui a finalidade de analisar, deliberar e aprovar projetos de regularização de parcelamento do solo e os loteamentos de interesse social ${ }^{32}$;1) Decreto $n^{\circ}$ 1442/2005, que trata sobre os critérios para regularização fundiária em áreas pertencentes à administração (direta e indireta). ${ }^{33}$

iii) Programas atuais relacionados a políticas habitacionais e ambientais correlatas a temáticas: a) Ambientais: Programa Compra do Lixo, destinado a áreas com sérios problemas ambientais devido à falta e/ou impossibilidade da coleta regular de lixo; tal deficiência se dá por estarem em áreas não urbanizadas ou de difícil acesso aos caminhões de coleta, como encostas de morros, fundos de vale e áreas de assentamentos irregulares com ruas estreitas. O objetivo do programa é ser uma forma alternativa de coleta domiciliar destinada à população menos favorecida; ${ }^{34}$ o Programa de Educação Ambiental busca sensibilizar os cidadãos sobre as questões ambientais, sendo incluído nas escolas e em diversos parques da cidade. ${ }^{35}$

b) Programas Habitacionais de Interesse Social desenvolvidos pela COHAB-CT: Programa Lotes urbanizados e Financiamento para material de construção: produção de unidades voltadas às famílias com renda de até três salários mínimos. Em tese, os lotes são entregues com infraestrutura básica (ruas ensaibradas, redes dedrenagem, água, esgoto e energia elétrica), e locais de acordo com o planejamento da cidade; ${ }^{36}$

Programa de Regularização Fundiária: voltado a famílias de menor renda, através da regularização ou reassentamento nos casos de impossibilidade de permanência no local de moradia. Ao fim, recebem o título de propriedade definitivo, o seu principal objetivo. Segundo o levantamento realizado pela prefeitura dos anos 80 até 2006, foram 32 BRASIL, Decreto Municipal de Curitiba nº 1164/2007. Disponível em: $<$ https://leismunicipais. com.br/a/pr/c/curitiba/decreto/2007/116/1164/decreto-n-1164-2007-institui-a-comissao-de-analise-eaprovacao-de-loteamentos-de-interesse-social-caalis $>$. Acesso em 27 de dezembro de 2017.

33 BRASIL, Decreto Municipal de Curitiba no 1442/2005. Disponível em: $<$ https://leismunicipais. com.br/a/pr/c/curitiba/decreto/2005/145/1442/decreto-n-1442-2005-dispoe-sobre-os-criterios-para-regularizacao-fundiaria-em-areas-pertencentes-a-administracao-direta-e-indireta-do-municipio-de-curitiba-ocupadas-por-populacao-de-baixa-renda-e-da-outras-providencias $>$. Acesso em 27 de dezembro de 2017.

34 INSTITUTO DE PESQUISA E PLANEJAMENTO URBANO DE CURITIBA. Plano Municipal De Regularização Fundiária Em Áreas De Preservação Permanente. Curitiba 2007. P.151. Disponível em: <http://www.ippuc.org.br/visualizar.php?doc=http://admsite2013.ippuc.org.br/arquivos/documentos/D312/D312_006_BR.pdf >. Acesso em 28 de dezembro de 2017.

35 INSTITUTO DE PESQUISA E PLANEJAMENTO URBANO DE CURITIBA. Plano Municipal De Regularização Fundiária Em Áreas De Preservação Permanente.... Op Cit.P.154.

36 INSTITUTO DE PESQUISA E PLANEJAMENTO URBANO DE CURITIBA. Plano Municipal De Regularização Fundiária Em Áreas De Preservação Permanente. ... Op Cit. P.155. 
atendidas 6.222 famílias. $^{37}$

Programa de Arrendamento Residencial (PAR), realizado em parceria com a Caixa Econômica Federal,e tem por objetivo substituir a compra financiada de unidades pelo procedimento do arrendamento, com prazo de 15 anos. Os números apresentados elencam que de 2001 a 2007 foram produzidas 3.194 unidades. $^{38}$

Programa de Parceria com a Iniciativa Privada, que surgiu no início da década de 90, como alternativa para a falta de recursos do Sistema Financeiro da Habitação (SFH). O parceiro privado assume todos os custos e compromete-se a transferir parte dos lotes produzidos ao Fundo Municipal da Habitação, que são ofertados pela COHAB-CT à população de até 3 salários mínimos; o restante pode ser vendido diretamente pelo empreendedor para famílias com renda superior a 3 salários mínimos. ${ }^{39}$

Alvará Simplificado para Moradia Popular, que consiste na elaboração de projetos, pelos técnicos da $\mathrm{COHAB}$, de casas térreas com até $70 \mathrm{~m}^{2}$ e na emissão de alvará autorizando a construção. As restrições são: que a família tenha renda de até 5 salários mínimos, tenha um único imóvel e que não exista outra edificação no lote. ${ }^{40}$

Fundo Municipal de Habitação (FMH), instituído em 1990, antes do Estatuto da Cidade; objetiva prover fundos próprios para o financiamento de programas habitacionais. ${ }^{41}$

Programa de Governo MORO AQUI, que trabalha em três frentes: a primeira é a urbanização através de obras de infraestrutura em áreas sem saneamento e com serviços precários (desde que não haja restrições técnicas ou legais). A segunda é a regularização fundiária e titulação das famílias e a terceira é a realocação de famílias de área de risco, que objetiva a transferência para loteamentos regulares das famílias que vivem em:“situação de risco,condições insalubres, áreas de preservação permanente, proteção ambiental, faixa de domínio de rodovias, ferrovias,

37 INSTITUTO DE PESQUISA E PLANEJAMENTO URBANO DE CURITIBA. Plano Municipal De Regularização Fundiária Em Áreas De Preservação Permanente.... Op Cit. P.156.

38 INSTITUTO DE PESQUISA E PLANEJAMENTO URBANO DE CURITIBA. Plano Municipal De Regularização Fundiária Em Áreas De Preservação Permanente.... Op Cit.P.156.

39 INSTITUTO DE PESQUISA E PLANEJAMENTO URBANO DE CURITIBA. Plano Municipal De Regularização Fundiária Em Áreas De Preservação Permanente.... Op. Cit.P.157.

40 INSTITUTO DE PESQUISA E PLANEJAMENTO URBANO DE CURITIBA. Plano Municipal De Regularização Fundiária Em Áreas De Preservação Permanente.... Op. Cit.P.158.

41 INSTITUTO DE PESQUISA E PLANEJAMENTO URBANO DE CURITIBA. Plano Municipal De Regularização Fundiária Em Áreas De Preservação Permanente.... Op. Cit.P.158. 
e linhas de alta tensão."42 Já estão em andamento os seguintes projetos: Bolsão Audi/União com ações de urbanização, Moradias Pinhão, com ações de reassentamento, Terra Santa, com ações de regularização e reassentamento, Vila Pantanal e Vila Bela Vista do Passaúna, com ações de urbanização e a Vila Savana e Lorena, com ações de urbanização e assentamento definitivo. ${ }^{43}$

Ainda se ressaltam os critérios do Plano Municipal de Regularização Fundiária em Áreas de Preservação Permanente, para análise dos assentamentos irregulares em Curitiba: a inserção no entorno; a topografia do setor; o grau de consolidação; a situação de risco e ainda a insalubridade; a acessibilidade; a infraestrutura; a situação dominial; a fase da regularização fundiária e as realocações necessárias. ${ }^{44}$

Como demonstrado, a legislação tanto constitucional como infraconstitucional está recheada de grandes intenções e, ainda, valoriza como fator primordial a integração entre os diferentes direitos que estão correlatos ao se tratar de habitação, promovendo a necessária relação com o planejamento urbano e o meio ambiente.O questionamento que resta é qual a situação real da relação entre os assentamentos irregulares e o meio ambiente.

42 INSTITUTO DE PESQUiSA E PLANEJAMENTO URBANO DE CURITIBA. Plano Municipal de Regularização Fundiária em Áreas de Preservação Permanente.... Op. Cit.P.159 e 160.

43 InSTITUTO DE PESQUiSA E PlANEJAMENTO URBANO DE CURITIBA. Plano Municipal de Regularização Fundiária em Áreas de Preservação Permanente.... Op. Cit.P.159 e 160. 44 InSTITUTO DE PESQUiSA E PLANEJAMENTO URBANO DE CURITIBA. Plano Municipal de Regularização Fundiária em Áreas de Preservação Permanente.... Op. Cit. P.184. 
3. ASSENTAMENTOS IRREGULARES EM CURITIBA E A DEGRADAÇÃO DO MEIO AMBIENTE: A REALIDADE

Primeiramente, pode-se observar a tabela ${ }^{45}$ representativa dos números absolutos de assentamentos irregulares:

Tabela 2 - Ocupações Irregulares por categoria no Município de Curitiba no ano de 2005

\begin{tabular}{|l|l|l|}
\hline Categoria & $\begin{array}{l}\text { Número } \\
\text { de áreas }\end{array}$ & $\begin{array}{l}\text { Número } \\
\text { de domicílios }\end{array}$ \\
\hline Assentamento espontâneos em regularização & 53 & 17.352 \\
\hline $\begin{array}{l}\text { Assentamentos espontâneos sem } \\
\text { regularização }\end{array}$ & 205 & 38.048 \\
\hline Loteamento clandestino em regularização & 10 & 2.101 \\
\hline Loteamento clandestino sem regularização & 73 & 4.765 \\
\hline TOTAL & 341 & 62.267 \\
\hline
\end{tabular}

Já com relação ao risco ambiental, denota-se que este representa a proporção de domicílios em condições inadequadas de saneamento. Dessa forma, $32 \%$ das áreas das grandes metrópoles foram classificadas como de médio-alto a altíssimo risco e, assim, das 36 áreas nessas condições, 6 estão em Curitiba, nos respectivos bairros: Augusta, Riviera, Orleans, Butiatuvinha, Lamenha Pequena, Tatuquara, Moradias de Ordem, Cajuru 2, Campo de Santana, Caximba, Umbará, Ganchinho e Uberaba.

Um fator essencial que se observa é que há uma segregação socioespacial e ambiental, ou seja,"são as áreas centrais do município-polo que reúnem as condições de mais baixo risco ambiental e a situação fica mais crítica à medida que as áreas se afastam desse ponto". ${ }^{46}$

Em específico, quanto aos assentamentos irregulares em áreas de preservação ambiental e áreas de preservação permanente,estes são

45 Tabela simplificada com case na tabela disponível em: INSTITUTO DE PESQUISA E PLANEJAMENTO URBANO DE CURITIBA. Plano Municipal de Regularização Fundiária. ... Op. Cit. Anexo I. p.5.

46 OBSERVATÓRIO DAS METRÓPOLES. Identificação dos espaços metropolitanos e construção de tipologias: relatório de atividade 1. [S.1.]: IPARDES, 2004. Projeto Análise das Regiões Metropolitanas do Brasil. Contrato Ministério das Cidades, FASE. Trabalho realizado por IPARDES, IPPUR, FASE. Disponível em: <http://www.observatoriodasmetropoles.ufrj.br/produtos/produto_mc_1.pdf $>$. Acesso em 20 de dezembro de 2017. 
apresentados na figura 2. Em números absolutos, os dados de assentamentos irregulares em áreas de preservação ambiental e permanente representam: 293 ocupações, sendo 251 em APP e 42 em APA, de um total atualizado de 397, em 2006. Em número de domicílios, as ocupações em APP representam um total de 13.136 domicílios; não foram encontrados dados específicos quanto à APA. ${ }^{47}$

\section{Figura 2- Percentual de pessoas em ocupações irregulares em APA e APP no ano de 2005}

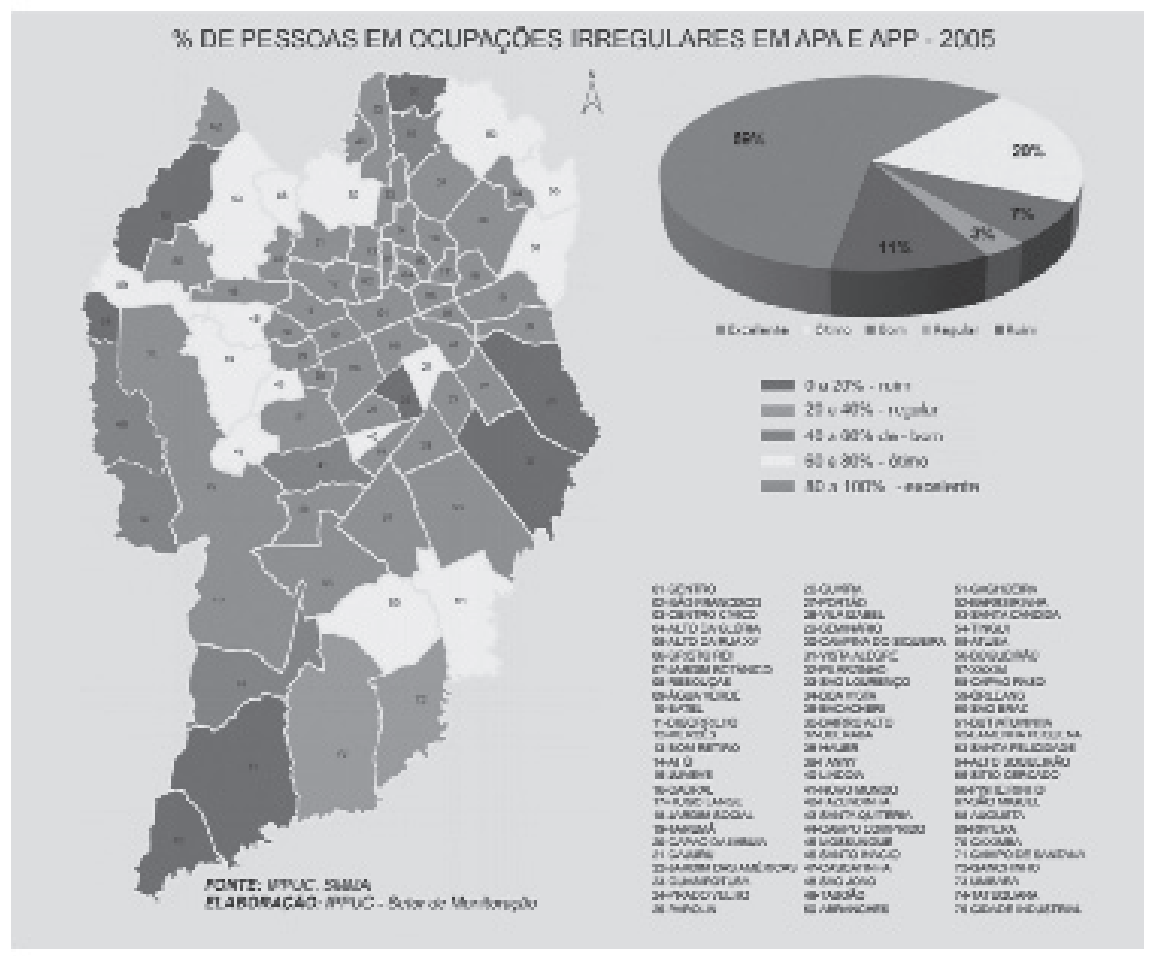

FONTE: Plano Diretor de Curitiba. Controle Ambiental e Desenvolvimento Sustentável. ${ }^{48}$

O questionamento ao qual se buscou responder é o que efetivamente está por trás das legislações: qual a vivência da população

47 BRASIL, Prefeitura Municipal de Curitiba. Plano Municipal de Habitação e Habitação de Interesse Social. 2008, p.77 a 84. Disponível em: <http://www.ippuc.org.br/mostrarpagina.php?pagina=312> Acesso em 28 de dezembro de 2017.

48 BRASIL, Plano Diretor de Curitiba. Lei Municipal no. 14.771/2015. ... Op. Cit.Controle Ambiental e Desenvolvimento Sustentável. Análise de Desempenho 1970 a 2009. P.55 
e quais os principais problemas que a cidade de Curitiba enfrenta no que tange aos assentamentos irregulares e a preservação do meio ambiente.

Como respostas, encontra-se que os problemas enfrentados hoje sobre a temática utilizada podem ser sintetizados em: i) Preço dos lotes; ii) Procedimento; iii) Transparência;iv) Fiscalização.

i) Com relação aos preços dos lotes, destaca-se em um primeiro momento o programa "parceria com a iniciativa privada" que, segundo a própria COHAB-CT, adveio como uma alternativa para a falta de recursos: "O empreendedor assume o investimento e compromete-se a fazer a transferência de $20 \%$ dos lotes produzidos ao Fundo Municipal da Habitação"; os outros $80 \%$ seriam vendidos diretamente pela empresa. ${ }^{49}$

Entretanto, destaca-se que o programa foi regulamentado pela Lei Municipal $n^{\circ} 8.412 / 1994$, que definiu como lote popular aquele que tivesse de $180 \mathrm{~m}^{2}$ a $360 \mathrm{~m}^{2}$ 50; entretanto, a área média dos lotes das parcerias privadas alcançava $160 \mathrm{~m}^{2}$ nas Moradias Rio Bonito, $140 \mathrm{~m}^{3}$ nas Moradias Riacho Doce e $136 \mathrm{~m}^{2}$ no Jardim Habitalar III. ${ }^{51}$ Além disso, não era o poder público que contratava a empresa privada e sim, a COHAB-CT, que é contratada pelas empresas para a prestação de serviços de assessoria técnica. ${ }^{52}$

Os valores dos lotes populares-privados que foram destinados a venda pela COHAB-CT (20\% da produção privada) em 2009, situavam-se entre $\mathrm{R} \$ 8.500,00$ e $\mathrm{R} \$ 10.000,00$, e a prestação geralmente era estipulada em 180 meses, alcançando R\$110,00/mês, destinados, a partir de 2002, a famílias de renda até 3 salários mínimos. ${ }^{53}$ Já os $80 \%$ restantes, que eram exclusividade das parceiras privadas, eram vendidos pelos valores de $\mathrm{R} \$ 16.000,00$ a $\mathrm{R} \$ 25.000,00$, financiados também em 180 meses, com prestações superiores a $\mathrm{R} \$ 200,00 .{ }^{54} \mathrm{Ou}$ seja, ao final, com a devida atualização e juros, os lotes alcançavam o valor final de R $\$ 28.800,00$ (Jardim Habitalar III) a R \$45.144,00 (Moradias Rio Bonito). ${ }^{55}$

49 COMPANHIA DE HABITAÇÃO POPULAR DE CURITIBA- COHAB-CT. Relatório de gestão 2002/2004. Curitiba: COHAB/CT, 2004, p.14-15.

50 BRASIL, Lei Municipal de Curitiba $n^{\circ}$ 8.412/1994.Art. $2^{\circ}$

51 ALBUQUERQUE, Aline Figueiredo. A questão habitacional em Curitiba: o enigma da "cidade-modelo". Dissertação de mestrado. Faculdade de Arquitetura e Urbanismo da Universidade de São Paulo, 2007, p.86.

52 ALBUQUERQUE, Aline Figueiredo. A questão habitacional em Curitiba... Op. Cit.p.86. 53 COMPANHIA DE HABITAÇÃO POPULAR DE CURITIBA- COHAB-CT. Relatório de gestão 2002/2004. Curitiba: COHAB/CT, 2004, p.14.

54 ALBUQUERQUE, Aline Figueiredo. A questão habitacional em Curitiba... Op. Cit.p.87.

55 Aplicavam-se ao primeiro os juros de $1 \%$ ao mês corrigido pelo INPC. Para uma análise de todas as formas de pagamento e os referidos juros das empresas da época consultar: ALBUQUERQUE, Aline 
Ainda, o próprio presidente da COHAB afirma que pode haver a variação dos valores devido ao próprio preço de custo do lote, e "como a COHAB é uma empresa, não pode ter prejuízo",fator que encarece os preços dos lotes, como no caso do Bolsão Formosa, que é vendido a $\mathrm{R} \$ 390,00$ por $\mathrm{m}^{2}$,"para equilibrar finanças". ${ }^{56}$

Além disso,a vice-presidente da Associação de Moradores Canãa, que compõe o Formosa, Indianara de Barros, informa que muitos moradores não conseguem dar entrada no financiamento de lotes, pois, como as prestações alcançariam valores de $\mathrm{R} \$ 500^{57}$, em parcelas de $20 \mathrm{e}$ poucos anos,as famílias deveriam comprovar renda mensal superior a $\mathrm{R} \$ 2$ mil, e muitas famílias não conseguem. ${ }^{58}$

ii) Com relação aos procedimentos adotados, o presidente da COHAB, Ubiraci Rodrigues, explicou o procedimento e as taxas do processo. Segundo ele,há duas variáveis na cobrança de valores: a primeira refere-se às tarifas e taxas do próprio processo, que inclui o trabalho administrativo da própria $\mathrm{COHAB} \mathrm{(levantamento} \mathrm{topográfico} \mathrm{dos} \mathrm{terrenos}$ e das ruas, aplicação de questionários aos moradores etc.), que custaria em 2006 o valor de R \$ 1,5 mil por morador, podendo ser parcelado em até 10 vezes. Além disso, ainda nesse primeiro estágio, o custo da escritura seria de $R \$ 300$ a R \$ 400. Ressalta ainda que há isenção de IPTU e, por ser habitação de interesse social, há isenções de Imposto sobre a Transmissão de Bens Móveis (ITBI) e no cartório de registro de imóveis.

A segunda variável diz respeito ao valor efetivo da cobrança do terreno. Segundo o presidente, a COHAB sempre adquire os lotes por meio de doação ou permuta; ainda ressalta que, em diversos casos, a prefeitura troca a área pelo perdão de dívidas dos proprietários e, assim, doa o imóvel à Cohab, que tenta repassar aos moradores pelo custo de $\mathrm{R} \$ 150$ por $\mathrm{m}^{2}$. Ressalta também que há a exceção dos moradores que pagaram integralmente pelos Termos de Uso e Concessão do Solo,os quais estariam isentos dessa parte. Entretanto, afirma ainda que esse valor pode variar devido ao próprio preço de custo do lote, que pode ser superior, como no caso do Bolsão Formosa, que é vendido a $\mathrm{R} \$ 390,00$ por $\mathrm{m}^{2}$,"para

Figueiredo. A questão habitacional em Curitiba... Op. Cit. p.89.

56 JORNAL GAZETA DO POVO, Quanto custa a regularização fundiária em Curitiba? 28.09.2016. Disponível em: < http://www.gazetadopovo.com.br/vida-e-cidadania/futuro-das-cidades/ quanto-custa-a-regularizacao-fundiaria-em-curitiba-0d0d6y2ijg48zljwfvelyhqhg $>$ Acesso em 10 de novembro de 2017.

57 Valores referentes ao ano de 2016.

58 JORNAL GAZETA DO POVO, Quanto custa a regularização fundiária em Curitiba?... Op. Cit. 
equilibrar finanças". 59

Paralelamente, há diversas críticas a respeito do desinteresse da própria instituição em realizar a regularização fundiária e, quando esta é realizada, a atuação da instituição se restringe a "propor a compra e venda dos terrenos ocupados entre os moradores e os proprietários"60, com supervalorizações dos terrenos e, assim, inviabilizando a efetiva negociação. A cobrança efetivada dessa forma e com esses valores faz com que vários moradores não permaneçam no local. ${ }^{61}$

Uma das críticas mais cruciais é a de que,hoje, a fila de espera dos programas habitacionais da COHAB possui mais de 80.000 inscritos. Atualmente, metade da produção de unidades habitacionais está destinada a reassentamento, ou seja, para atender famílias que foram removidas ${ }^{62}$. Como constatado anteriormente, ainda há grandes percentuais de famílias sem locais adequados, além das que estão em áreas de preservação ambiental e permanente, fator que não vem sendo contado como prioridade nos reassentamentos da $\mathrm{COHAB}$.

Além disso, cabe ressaltar que, em 2002,o Ministério Público do Paraná moveu uma Ação Civil Pública que denunciou o caráter fraudulento dos contratos realizados pela $\mathrm{COHAB}$ através de termos de concessão e uso com os moradores. O procedimento da referida instituição era ceder o uso de terrenos através de "Termos de Concessão de Uso de Solo".

Entretanto, como constatado pelo Ministério Público e confirmado em sentença de primeiro grau e acórdão de segundo grau, os referidos contratos eram feitos sob propriedade que não pertence à $\mathrm{COHAB}$. Sabese, inclusive, que a própria instituição informou nos autos que os lotes pertencem à Companhia de Desenvolvimento de Curitiba - CIC. Dessa forma, constatou-se o vício em todos os contratos firmados pela COHAB desde 1994 e, assim, foram todos invalidados. ${ }^{63}$ Ressalta-se que, no total,

59 JORNAL GAZETA DO POVO, Quanto custa a regularização fundiária em Curitiba?... Op. Cit.

60 MEIRINHO, Bruno Cesar Dechamps; ROCHA, Líbina da Silva; AULER, Mariana Marques.Regularização fundiária: política pública ou negócio? Como Curitiba propõe a regularização de assentamentos autoconstruídos. $O$ mito do planejamento urbano democrático: reflexões a partir de Curitiba. Mobiliza Curitiba. Organização de Luana Xavier Pinto Coelho. - Curitiba: Terra de Direitos, 2015, p.103.

61 MEIRINHO, Bruno Cesar Dechamps; ROCHA, Líbina da Silva; AULER, Mariana Marques.Regularização fundiária: política pública ou negócio?... Op. Cit.p.103 - 106.

62 MOBILIZA CURITIBA, Política Pública de moradia Popular. O mito do planejamento urbano democrático: reflexões a partir de Curitiba. Mobiliza Curitiba. Organização de Luana Xavier Pinto Coelho. - Curitiba: Terra de Direitos, 2015, p.81

63 BRASIL, Tribunal de Justiça do Paraná. Apelação em Ação Civil Pública n 0386783-8. Ação civil pública n 38910/2002. Relator Desembargadora Rosene Arão de Cristo Pereira. 
37.751 imóveis estavam arrolados no processo e, deste número, 6.539 ainda não foram regularizados, podendo, ainda, ter os valores das parcelas renegociados ${ }^{64}$.

iii) A questão da transparência é muito evidenciada nas reclamações e relatos populares. Primeiramente, a respeito do procedimento efetuado pela $\mathrm{COHAB}$, elencado pelo presidente da instituição no ponto "ii", a promotora Aline Balek Bahr, da Promotoria de Justiça de Habitação e Urbanismo de Curitiba, afirma que boa parte desses conflitos entre moradores e a $\mathrm{COHAB}$ poderia ser resolvida ou ao menos minimizada, se houvesse mais transparência no processo, inclusive ressalvando que este poderia ser um fator que traria mais segurança aos moradores. ${ }^{65}$

A criação do CONCITIBA, conselho municipal de Curitiba, um conselho formado por diversas entidades e conselhos municipais com o objetivo de integrar as ações de política urbana, traz a esperança da abertura do diálogo. Entretanto, ao se analisar as pautas discutidas nesse conselho, denota-se que $47 \%$ delas se relacionam a questões de organização interna do Conselho e somente $27 \%$ tratam sobre o planejamento urbano. ${ }^{66}$

Dessa forma, a primeira crítica que se apresenta é quanto à própria possibilidade de participação e acompanhamento do processo decisório da cidade. O movimento Mobiliza Curitiba informa que, quando foram inauguradas as discussões a respeito da revisão do Plano Diretor, não havia clareza de quantas audiências públicas seriam realizadas, como cada cidadão poderia participar realizando propostas, como seriam feitas as avaliações e julgamentos dessas propostas e qual seria o papel do CONCITIBA em todo esse processo. ${ }^{67}$

Relata também que, em determinado momento, a situação de obscuridade de transparência chegou a um patamar em que foi necessário exigir que condições mínimas fossem cumpridas como: audiências públicas em locais e horários acessíveis, a disponibilização de material informativo antes das audiências públicas, a ampla divulgação dessas discussões, uma

64 TERRA DE DIREITOS, Contratos falsos da COHAB-CT. 02/03/2013. Disponível em: < http:// terradedireitos.org.br/casos-emblematicos/contratos-falsos-da-cohabct/11570>. Acesso em 30 de dezembro de 2017.

65 JORNAL GAZETA DO POVO, Quanto custa a regularização fundiária em Curitiba? ... Op. Cit.

66 BRAGA, Andréa Luiza Curralinho. Reflexões sobre o Conselho Municipal da Cidade de Curitiba: dilemas e desafios da participação e do planejamento urbano. O mito do planejamento urbano democrático: reflexões a partir de Curitiba. Mobiliza Curitiba. Organização de Luana Xavier Pinto Coelho. - Curitiba: Terra de Direitos, 2015, p.47-49.

67 MOBILIZA CURITIBA, Política Pública de moradia popular. O mito do planejamento ... Op. Cit.p.34. 
plataforma virtual para possibilitar o monitoramento das propostas e, ainda, a explicação das propostas da gestão e os critérios para o julgamento das propostas que foram apresentadas. ${ }^{68}$

Diversas críticas são proferidas quanto a possibilidades de participação da população e, atrelada a isso, a questão da informação. A representante do movimento União por Moradia Popular, Giziane Rodrigues, ressalta que falta esse trabalho de base, pois, afinal,"as pessoas queriam debater, mas não sabiam como" e, assim, para que se garanta uma discussão efetiva, é necessário que a população saiba a utilidade e quais as possibilidades dos institutos legais, como o próprio Plano Diretor. ${ }^{69}$

Há ainda posições mais críticas como a representante do Movimento Nacional da Luta pela Moradia, Hilma de Lourdes Santos, que ressalta que uma das perspectivas observadas ao participar da construção do Plano Diretor era que a participação popular e da sociedade civil seria "apenas uma ferramenta para legitimar o que querem por em ação". ${ }^{70}$

O representante do Movimento Nacional da População em Situação de Rua de Curitiba, Maurício Pereira, traz a importante denúncia de que, se não fosse a participação da própria sociedade civil como o movimento Mobiliza Curitiba, outros movimentos sequer saberiam das datas de reuniões para a construção do Plano Diretor do município. ${ }^{71}$

iv) O último ponto a ser estudado é a fiscalização. Em um primeiro momento, retoma-se o que foi anteriormente apresentado, principalmente no ponto ii, no que tange à variável relativa ao preço dos lotes,à Ação Civil pública que demonstrou a irregularidade dos processos da $\mathrm{COHAB}$, e aos próprios procedimentos para compra de lotes e regularizações. A promotora Aline Balek Bahr defende que, para a real efetivação das propostas da $\mathrm{COHAB}$, há a necessidade de instâncias de controle social que fiscalizariam todo o processo de compra e regularização, incluindo a lista de espera da companhia, as prioridades para cada segmento (faixas

68 MOBILIZA CURITIBA, Política Pública de moradia popular. O mito do planejamento ... Op. Cit.p.34.

69 RODRIGES, Giziane. Depoimentos. O mito do planejamento urbano democrático: reflexões a partir de Curitiba. Mobiliza Curitiba. Organização de Luana Xavier Pinto Coelho. — Curitiba: Terra de Direitos, 2015, p.130.

70 SANTOS, Hilma de Lourdes Santos. Depoimentos. O mito do planejamento urbano democrático: reflexões a partir de Curitiba. Mobiliza Curitiba. Organização de Luana Xavier Pinto Coelho. — Curitiba: Terra de Direitos, 2015, p.130.

71 PEREIRA, Maurício. Depoimentos. O mito do planejamento urbano democrático: reflexões a partir de Curitiba. Mobiliza Curitiba. Organização de Luana Xavier Pinto Coelho. — Curitiba: Terra de Direitos, 2015, p.131. 
1, 2 e 3 do FGTS) e, ainda, a situação das áreas em regularização. ${ }^{72}$ Dessa forma, impediria a maior consequência que foi demonstrada nesse estudo: a invalidação de milhares de contratos por apresentarem vícios, como no caso dos termos de uso utilizados pela $\mathrm{COHAB}$ em terrenos que não eram de sua propriedade. Nesse mesmo sentido, uma instância de controle é necessária para a fiscalização das expansões, principalmente quando se trata de áreas de preservação ambiental e permanente.

Este ponto está diretamente refletido nos dados anteriormente apresentados no ponto 3, uma vez que, apesar dos conturbados esforços apresentados pela prefeitura de Curitiba em realizar reassentamentos, regularizações fundiárias e os mecanismos de facilitação de pagamentos,estes não foram suficientes para barrar o crescimento dos assentamentos irregulares, com o agravante de que o crescimento destes em áreas de preservação ambiental e permanente é preocupante. Afinal, $13 \%$ dos bairros de Curitiba encontram-se em situações péssimas ou regulares no que tange a ocupações irregulares em APA ou APP, e destacase ainda que a regional Cajuru é a que está em pior situação:30,51\% dos seus domicílios em área de APA e/ou APP e 37,85\% de sua população nessa condição. ${ }^{73}$

Os dados demonstram que as políticas habitacionais e principalmente de proteção ao meio ambiente diretamente afetado não estão se mostrando suficientes, e ainda, mesmo diante de estatísticas e mapas elaborados por órgãos vinculados à própria prefeitura denunciarem o crescimento de ocupações irregulares em áreas de preservação ambiental e permanente, poucas e esparsas são as ações executadas com o objetivo de fiscalizar a expansão do crescimento de áreas que já estão nessa situação e, assim, evitar tais expansões, possibilitando que os habitantes construam sua moradia em áreas adequadas.

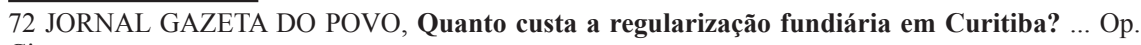
Cit.

73 BRASIL, Plano Diretor de Curitiba. Lei Municipal nº 14.771/2015. Controle Ambiental e Desenvolvimento Sustentável. Análise de Desempenho 1970 a 2009. P.55 Disponível em: : $<$ http:// www.ippuc.org.br/visualizar.php?doc=http://admsite2013.ippuc.org.br/arquivos/documentos/D310/ D310_001_BR.pdf> Acesso em 20 de dezembro de 2017. 


\section{PONDERAÇÃO EM CONJUNTO PARA A SOLUÇÃO DO CONFLITO ENTRE ASSENTAMENTOS IRREGULARES E PROTEÇÃO AO MEIO AMBIENTE}

Ao se adentrar nas problemáticas elencadas anteriormente, é possível traçar algumas inspirações que possibilitariam a resolução desses problemas, ressalvando sempre que é necessária uma atuação integrada entre o Poder Público e a sociedade civil, uma vez que fazem parte do mesmo elo de construção de cidades sustentáveis e dignas para todos. ${ }^{74}$

O que se observa é que somente legislações, como o próprio Estatuto da Cidade, não resolvem ou eliminam os problemas e conflitos que a população vivencia na realidade, mas possuem o condão de tirá-los da sombra, "mostrando que a sociedade é desigualmente constituída". ${ }^{75} \mathrm{Dessa}$ forma,não cabe a este estudo traçar soluções mágicas ou técnicas para a solução completa das demandas dos moradores e também de proteção total do meio ambiente; há um equilíbrio entre esses fatores que vem sendo discutido na academia e que carece de soluções multidisciplinares: a integração de diversas áreas em prol do desenvolvimento real, abrangendo todos os interesses e as possibilidades técnicas. Não cabe ao Direito interferir ou opinar em soluções técnicas mas, sim,jurídicas, como revisão de legislações e ampliação de mecanismos de fiscalização. A função do Direito engloba a denúncia e a regulamentação, que, na maioria das vezes, só é possível ser efetivada com integração de estudos técnicos.

Sendo assim,o primeiro fator a ser ponderado de forma prioritária é a fiscalização intensa. Como demonstrado anteriormente, esse é um ponto que afeta diretamente diversos aspectos dos assentamentos irregulares e da sua interferência no meio ambiente. Uma fiscalização real dos contratos e dos procedimentos possibilitaria evitar diversas das consequências elencadas anteriormente, como a cobrança de preços exorbitantes, a utilização de termos de concessão de uso inadequados que, posteriormente, ensejaram a anulação de milhares de contratos, além de possibilitar o aumento da confiabilidade da população afetada no processo.

Efetivamente, é importante pensar nos assentamentos

74 SANCHES, Jussara Romero Sanches; ARAUJO JUNIOR, Miguel Etinger de. Multidimensionalidade do direito à cidade no estatuto da cidade.Revista de DireitoUrbanístico, Cidade e Alteridade. e-ISSN: 2525-989X. Brasília, v. 3, n. 1,Jan/Jun. 2017, p.4.

75 RODRIGUES, Arlete Moysés. Estatuto da Cidade: função social da cidade e da propriedade. Alguns aspectos sobre população urbana e espaço. Cadernos Metrópole, n. 12, $2^{\circ}$ sem., 2004, p. 12. 
irregulares e nos procedimentos para a regularização como uma política pública e, como isso requer seu aperfeiçoamento e fiscalização, não é possível vislumbrar essas situações como um "negócio" da COHAB ou do Poder Público. ${ }^{76}$ Somente através de um pensamento de progressividade e efetividade desses direitos como objetivos e realidades da cidade, será possível assegurar todos os direitos envolvidos e a moradia digna em conjunto com a proteção do ambiente.

Ademais, cabe a este estudo ressaltar que a fiscalização é o fator essencial para a avaliação e a contenção de expansões que alcançam áreas de preservação ambiental e permanente. A atuação fiscalizatória em questões ambientais é essencial, pois se trata de uma "corrida contra o tempo"; é necessário barrar as expansões nessa área e priorizar os estudos técnicos de possibilidade de reassentamentos, levando em conta a socialização e integração com a própria cidade. Diversos autores têm destacado a ineficiência de órgãos de fiscalização, principalmente devido à falta de suporte institucional disponível,além de existirem poucos agentes fiscalizadores, fatores que contribuem diretamente para a demora e para as falhas na comprovação do uso indevido das APP. ${ }^{77}$

Dessa forma, a atuação do poder público como agente fiscalizatório nas questões ambientais é essencial; não é admissível esperar a conscientização da sociedade como um todo para somente nesse momento atuar; mas, é possível contar com ela para a real efetivação desse processo ${ }^{78}$, e principalmente é necessário que o meio ambiente se torne efetivamente uma prioridade, sendo um elemento chave para o pensar acerca de uma política pública habitacional.

Além disso, é necessária a atuação de ONG's como o Centro de Estudos, Defesa e Educação Ambiental, Mater Natura - Instituto de Estudos Ambientais, Sociedade de Pesquisa em Vida Selvagem e Educação Ambiental (SPVS); movimentos como o Mobiliza Curitiba, a União por Moradia Popular, o Movimento Nacional de Luta pela Moradia; e a Associação de moradores. Tal atuação é necessária, principalmente

76 MEIRINHO, Bruno Cesar Dechamps; ROCHA, Líbina da Silva; AULER, Mariana Marques. Regularização fundiária: política pública ou negócio? ... Op. Cit.p.104.

77 BASSO, V. M. et al. Avaliação da influência da certificação florestal no cumprimento da legislação ambiental em plantações florestais. Revista Árvore, Viçosa-MG, v.35, n.4, p.835-844, jul./ago. 2011; e RODRIGUES, E. R. CULlEN JR., L.; BELTRAME, T. P.; MOSCOGLIATO, A. V.; SiLVA, I. C. Avaliação econômica de sistemas agroflorestais implantados para recuperação de reserva legal no Pontal do Paranapanema, São Paulo. Revista Árvore, v.31, n.5, p.941-948, Viçosa-MG, 2007.

78 BENJAMIN, Antônio Herman. Constitucionalização do ambiente e ecologização da Constituição Brasileira. In: CANOTILHO, José Joaquim Gomes; LEITE, José Rubens Morato (Org.). Direito constitucional ambiental brasileiro. 5. ed. rev. São Paulo: Saraiva, 2012. 
como mecanismo de denúncia de irregularidades e obscuridades, com a sociedade civil atuando como fiscalizatória das ações do Poder Público. Dessa forma, o primeiro ponto a ser pensado é a fiscalização por meio do próprio poder público, e o segundo ponto é a fiscalização por meio da sociedade, que, consequentemente, estará atrelada diretamente ao diálogo.

Como se observou, os mecanismos atuais de participação principalmente focados em audiências públicas direcionadas à discussão sobre legislações específicas, e assim, de certa forma sazonais, não possibilitam a participação efetiva e a visibilidade dos questionamentos e,tal como destacado anteriormente, muitas vezes os movimentos sociais e a sociedade civil são invisibilizados.

O diálogo real entre sociedade e Estado permite que a realidade dos assentamentos irregulares seja realmente vislumbrada e, também, as necessidades ambientais sejam compreendidas pela população e agentes públicos envolvidos. Há a necessidade de um planejamento pactuado com a sociedade. ${ }^{79} \mathrm{O}$ equilíbrio entre os problemas habitacionais e a questão ambiental está também calcado em um diálogo efetivo, de troca de experiências e de explicações pormenorizadas das necessidades urbanas e ambientais.

Dessa forma, é necessário que o Poder Público implemente mecanismos de participação não sazonais mas, sim, permanentes, para que a sociedade, as ONG's e os movimentos possam trazer à tona as suas demandas e estas serem realmente postas em discussão e análise. Assim, com as demandas efetivamente encaminhadas, poder-se-á caminhar para mecanismos de diálogo real,por meio do qual as ideias possam ser colocadas em discussão, com o objetivo de construir uma cidade integrada, participativa e que possibilite a vivência de todas, ou seja, é através do intercâmbio de experiências que haverá a cooperação, podendo-se alcançar fins comuns. ${ }^{80}$

Efetivamente, para a materialização desses objetivos,são necessárias a formulação, através de leis e políticas públicas, de mecanismo digitais e presenciais (descentralizados pelos bairros) e a efetivação de audiências públicas periódicas em busca de soluções integradas, com prazos de divulgação, com material informacional para a população, sendo estas audiências realizadas nas diversas regiões. Não há como se 79 TONELLA, Celene. Políticas Urbanas no Brasil: marcos legais, sujeitos e instituições. Revista Sociedade e Estado. Volume 28 Número 1. Janeiro/Abril 2013. P.50.

80 CUNHA, Luis Henrique; BRANQUINHO NUNES, Aldo Manoel. Proteção da natureza e conflitos ambientais em assentamentos rurais. Desenvolvimento e Meio Ambiente, n. 18, p. 27-38, jul./dez. 2008. Editora UFPR, p.37. 
pensar em uma política urbana que não abranja a participação social, e o fortalecimento do papel do Estado como condutor desse processo, atuando diretamente em favor e baseado na cidadania e democracia ${ }^{81}$ Trata-se de uma política pública de participação na gestão habitacional, que afeta diretamente a ambiental.

Dessa forma, trata-se de uma atuação da própria sociedade para a resolução dos problemas, fato que é plenamente possível quando se trata da precarização habitacional. Destaca-se novamente que é necessário o diálogo com essas instituições e a formação de verdadeiras parcerias; o Estado não consegue atuar sozinho,pode e deve reconhecer as ações realizadas pela sociedade com o objetivo de aprimorar e dignificar o espaço urbano. Entretanto, é importante ressaltar que a atuação no que diz respeito à proteção ao meio ambiente $\mathrm{e}$, consequentemente, aos assentamentos em APA e APP, devem ser realizadas predominantemente pelo Poder Público ${ }^{82}$, uma vez que, ao menos no que tange aos assentamentos irregulares, são questões que muitas vezes não agradam ao público envolvido, pois até hoje a solução encontrada são os reassentamentos.

Além desse papel fiscalizatório, um papel essencial do Estado é o de informar e ensinar sobre normas ambientais,como destaca Vladimir Passos de Freitas. Somente através da formação de uma cultura nesse sentido é que haverá o envolvimento da população e, assim,a vontade comum em efetivá-las. ${ }^{83}$ A juíza Pepita Durski Tramontini Mazini complementa essa relação ressaltando que o Poder Público pode, sim, prestar informações a esse respeito, e esta iniciativa é essencial, uma vez que "só se preserva e só se valoriza o que se conhece" ${ }^{84}$

Fiscalizar, dialogar e ensinar sobre esse assunto são de extra importância para que a sociedade vislumbre o meio ambiente como parte de suas vidas, dando prioridade à sua preservação.

Por fim, é crucial entender que as políticas públicas ambientais são de extrema urgência; a degradação ambiental deve ser evitada ao máximo,

81 MENDONÇA, Francisco. Riscos, vulnerabilidade e abordagem socioambiental urbana: uma reflexão a partir da RMC e de Curitiba. Desenvolvimento e Meio Ambiente, n. 10, p. 139-148, jul./dez. 2004. Editora UFPR, p.148.

82 Há casos em que a própria sociedade denunciou desgastes ambientais em áreas de preservação próximas a assentamentos. Sobre o tema consulte: CUNHA, Luis Henrique; BRANQUINHO NUNES, Aldo Manoel. Proteção da natureza e conflitos ambientais em assentamentos rurais. Desenvolvimento e Meio Ambiente, n. 18, p. 27-38, jul./dez. 2008. Editora UFPR, p.35.

83 FREITAS, Vladimir Passos de. Matas ciliares. In: FREITAS, Vladimir Passos de. (Org.)Direito Ambiental em evolução. Curitiba: Juruá, 2005, p.317

84 MAZINI, Pepita DurskiTramontini.O direito à informação ambiental. In: FREITAS, Vladimir Passos (Org.). Direito ambiental em revolução 1. Curitiba: Juruá, 2002, p14-15. 
ao mesmo tempo em que soluções precisam ser pensadas e principalmente efetivadas quando se pensa em assentamento irregulares. Novamente, o equilíbrio entre esses dois interesses distintos está em reconhecer que, em realidade, trata-se de dois interesses convergentes: o desenvolvimento pleno da cidade.

A sociedade alcançou uma complexidade de interesses e de problemáticas, principalmente diante de fenômenos ambientais que geram catástrofes, como grandes enchentes e desabamentos. Nesse momento, a ideia de risco ambiental liga-se ao mesmo tempo às Ciências da Natureza e às Ciências da Sociedade e, assim, trazem uma abordagem completamente diferente. ${ }^{85} \mathrm{Os}$ riscos urbanos são um "combinado de um "álea"(fenômeno aleatório) e de uma vulnerabilidade". ${ }^{86}$ Por esse motivo, as condições de vida da população passam a possuir um importante papel na própria compreensão e constituição dos problemas ambientais urbanos, e atuam como fator determinante para deixar evidente a cidade formal e informal ${ }^{87}$,como destacado anteriormente, em que a degradação ambiental assume maiores proporções em regiões periféricas e discriminadas, configurando um agravante, tendo em vista a cidade informal que se forma na periferia. ${ }^{88}$

O desenvolvimento que se busca só poderá ser alcançado através da integração desses interesses. Moradias dignas só alcançarão esse status quando a preservação do meio ambiente for também parte desse processo.Essa integração está diretamente relacionada à sustentabilidade, entendida como o "reconhecimento de limites biofísicos colocados, incontornavelmente, pela biosfera no processo econômico" 89 , ou seja, perceber que a ecologia sustenta a economia, e, assim, qualquer política que objetiva restringir impactos de desigualdade econômica deverá levar em consideração e estar em sintonia com a natureza.

Atualmente a política habitacional e o meio ambiente estão integradas somente em proibições de ocupações e no Plano Municipal de regularização fundiária em áreas de preservação permanente, o que não

85 MENDONÇA, Francisco. Riscos, vulnerabilidade e abordagem socioambiental urbana... Op. Cit. p. 141.

86 DUBOIS-MAURY, J.; CHALINE, C. Les risquesurbains. Paris: Armand Colin, 2002.

87 MENDONÇA, Francisco. Riscos, vulnerabilidade e abordagem socioambiental urbana... Op. Cit. p. 141 .

88 GRAZIA, G.; QUEIROZ, L. L. et al. O desafio da sustentabilidade urbana. Rio de Janeiro: FASE/ IBASE, 2001. (Série Cadernos Temáticos, n. 5) p.91.

89 CAVALCANTI, Clóvis de Vasconcelos. Desenvolvimento e natureza: estudos para a sociedade sustentável. 2. ed. São Paulo: Cortez, 1998, p.134. 
vem se demonstrando suficiente para reforçar a linha de ligação que essas duas matérias e realidades possuem. Ou seja, as demandas atuais para a moradia, em diversos pontos, não encontram a resposta adequada em uma política pública específica, e a delimitação de seu conteúdo encontra essa dificuldade, por não estar presente em um projeto atual. ${ }^{90}$ Ao mesmo tempo, elas, na realidade, alcançam as demandas de proteção ao meio ambiente, mas, nos planos, as duas exigências não estão relacionadas como deveriam. Para o desenvolvimento pleno e digno da cidade é necessário que tanto a política pública habitacional como a de proteção ao meio ambiente sejam repensadas, de forma a abranger em cada uma delas essa interligação que já se vislumbra na realidade: o meio ambiente e a sociedade. A criação de cidades sustentáveis depende dessa integração.

\section{CONCLUSÃO}

A este estudo restaram quatro momentos de análises: primeiramente, a regulamentação internacional, constitucional e federal sobre os temas que circundam a temática dos assentamentos irregulares e da proteção ao meio ambiente, demonstrando a multidisciplinaridade deste estudo. Em um segundo momento, adentrou-se no Plano Diretor de Curitiba/PR, nas legislações municipais esparsas e nos programas que atualmente vigoram quando se trata de moradias em regiões precarizadas, bem como na proteção do meio ambiente envolvido. Em um terceiro momento, afastou-se do plano teórico legislativo, buscando diversas fontes para demonstrar os reais problemas vivenciados pelos moradores e medir o avanço das ocupações em áreas de preservação ambiental e permanente. No quarto momento, adentra-se nas inspirações que poderiam ajudar na construção de soluções quando diante da controvérsia entre os assentamentos irregulares e a proteção ambiental.

Dessa forma, pensar no equilíbrio entre os interesses dos moradores e do meio ambiente transpassa pelos seguintes tópicos: i) Fiscalização intensa e real dos contratos, dos procedimentos e da contenção de expansões que alcançam áreas de preservação ambiental e permanente, sendo esta responsabilidade tanto do Poder Público quanto da sociedade civil;ii) É esse intercâmbio de ideias que permite alcançar o segundo

90 VALLE, Vanice Lírio do. Demandas derivadas e ampliação do núcleo essencial do direito à moradia: Deferência como critério judicial de solução.In: José Ribas Vieira; Margarida Maria Lacombe Camargo; Rogerio Barros Sganzerla. (Org.). Direitos fundamentais e jurisdição constitucional. 1ed.Belo Horizonte: Editora Fórum, 2016, v. 1, p.191. 
ponto: o diálogo, uma vez que permitiria um sistema eficaz de feedback de políticas públicas em curso e possibilitaria a ampliação de ações no sentido de que efetivamente se afetassem e se alcançassem as demandas da população, bem como possibilitaria que o meio ambiente se tornasse uma demanda de toda a sociedade; ii) Por fim, é necessário pensar as políticas habitacionais em conjunto com as ambientais, para que, de forma integrada e progressista, caminhem juntas para o desenvolvimento de uma sociedade efetivamente digna, que garante os parâmetros ambientais.

\section{REFERÊNCIAS}

ALBUQUERQUE, Aline Figueiredo. A questão habitacional em Curitiba: o enigma da "cidade- modelo". Dissertação de mestrado. Faculdade de Arquitetura e Urbanismo da Universidade de São Paulo, 2007.

ALFONSIN, Betânia de Moraes. Da Invisibilidade à Regularização Fundiária: a trajetória legal da moradia de baixa renda em Porto Alegre. In: FERNANDES,Edésio; ALFONSIN, Betânia de Moraes (Coord. E coautores). A lei e a ilegalidade na produção do espaço urbano.Belo Horizonte: Del Rey, 2003.

ALVES, Carolina Caraíba Nazareth. Direito à moradia: análise da situação no município de Curitiba à luz de indicadores sociais. Dissertação (Mestrado em Direito das Relações Sociais) -Programa de Pós-Graduação em Direito da Universidade Federal do Paraná, Curitiba, 2010 .

BASSO, V. M. et al. Avaliação da influência da certificação florestal no cumprimento da legislação ambiental em plantações florestais. Revista Árvore, Viçosa-MG, v.35, n.4, p.835-844,jul./ago. 2011.

BENJAMIN, Antônio Herman. Constitucionalização do ambiente e ecologização da Constituição Brasileira. In: CANOTILHO, José JoaquimGomes; LEITE, José Rubens Morato (Org.). Direito constitucional ambientalbrasileiro. 5. ed. rev. São Paulo: Saraiva, 2012.

BRAGA, Andréa Luiza Curralinho. Reflexões sobre o Conselho Municipal da Cidade de Curitiba: dilemas e desafios da participação e do planejamento urbano. $\mathrm{O}$ mito do planejamento urbano democrático: 
reflexões a partir de Curitiba. Mobiliza Curitiba. Organização de Luana Xavier Pinto Coelho. - Curitiba: Terra de Direitos, 2015.

BRASIL, Decreto Municipal de Curitiba $\mathbf{n}^{\mathbf{0}}$ 1164/2007. Disponível em: <https://leismunicipais.com.br/a/pr/c/curitiba/decreto/2007/116/1164/ decreto-n-1164-2007-institui-a-comissao-de-analise-e-aprovacao-deloteamentos-de-interesse-social-caalis $>$. Acesso em 27 de dezembro de 2017.

BRASIL,Decreto Municipal de Curitiba $n^{0}$ 1442/2005. Disponível em: $<$ https://leismunicipais.com.br/a/pr/c/curitiba/decreto/2005/145/1442/ decreto-n-1442-2005-dispoe-sobre-os-criterios-para-regularizacaofundiaria-em-areas-pertencentes-a-administracao-direta-e-indireta-domunicipio-de-curitiba-ocupadas-por-populacao-de-baixa-renda-e-daoutras-providencias $>$. Acesso em 27 de dezembro de 2017.

BRASIL,Decreto Municipal de Curitiba $n^{0}$ 196/2000. Disponível em: $<$ https://leismunicipais.com.br/a/pr/c/curitiba/decreto/2000/19/196/ decreto-n-196-2000-regulamenta-a-lei-n-9802-00-que-instituiuincentivos-para-implantacao-de-programas-habitacionais-de-interessesocial-e-da-outras-providencias>. Acesso em 27 de dezembro de 2017.

BRASIL,Decreto Municipal de Curitiba $n^{0}$ 250/2000. Disponível em: $<$ https://leismunicipais.com.br/a/pr/c/curitiba/decreto/2000/25/250/ decreto-n-250-2000-dispoe-sobre-a-criacao-de-novos-setores-especiaisde-habitacao-de-interesse-social>. Acesso em 27 de dezembro de 2017.

\section{BRASIL, Lei Municipal de Curitiba nº 8.412/1994.}

BRASIL,Lei Municipal de Curitiba $\mathbf{n}^{\mathbf{0}}$ 9800/2000. Disponível em: $<$ https://leismunicipais.com.br/plano-de-zoneamento-uso-e-ocupacaodo-solo-curitiba-pr $>$. Acesso em 27 de dezembro de 2017.

BRASIL,Lei Municipal de Curitiba n⿳90802/2000. Disponível em: $<$ https:// leismunicipais.com.br/a/pr/c/curitiba/lei-ordinaria/2000/981/9802/ lei-ordinaria-n-9802-2000-institui-incentivos-para-a-implantacao-deprogramas-habitacionais-de-interesse-social-e-revoga-a-lei-n-7841-91>. Acesso em 27 de dezembro de 2017.

BRASIL,Lei Municipal de Curitiba n ${ }^{\circ}$ 9803/2000.Disponível em: $<$ https:// leismunicipais.com.br/a/pr/c/curitiba/lei-ordinaria/2000/980/9803/ 
lei-ordinaria-n-9803-2000-dispoe-sobre-a-transferencia-de-potencialconstrutivo $>$. Acesso em 27 de dezembro de 2017.

BRASIL, Lei Municipal de Curitiba n ${ }^{0}$ 9804/2000. Disponível em: $<$ https:// leismunicipais.com.br/a/pr/c/curitiba/lei-ordinaria/2000/980/9804/leiordinaria-n-9804-2000-cria-o-sistema-de-unidades-de-conservacaodo-municipio-de-curitiba-e-estabelece-criterios-e-procedimentos-paraimplantacao-de-novas-unidades-de-conservacao>. Acesso em 27 de dezembro de 2017.

BRASIL,Lei Municipal de Curitiba n⿳9805/2000. Disponível em: $<$ https:// leismunicipais.com.br/a/pr/c/curitiba/lei-ordinaria/2000/980/9805/leiordinaria-n-9805-2000-cria-o-setor-especial-do-anel-de-conservacaosanitario-ambiental-e-da-outras-providencias $>$. Acesso em 27 de dezembro de 2017.

BRASIL,Lei Municipal de Curitiba n⿳0 9806/2000. Disponível em: $<$ https:// leismunicipais.com.br/a/pr/c/curitiba/lei-ordinaria/2000/980/9806/leiordinaria-n-9806-2000-institui-o-codigo-florestal-do-municipio-decuritiba-revoga-as-leis-n-8353-93-e-8436-94-e-da-outras-providencias $>$. Acesso em 27 de dezembro de 2017.

BRASIL,Lei Municipal de Curitiba no7833/1991. Disponível em: $<$ http:// legisladocexterno.curitiba.pr.gov.br/AtosConsultaExternaDownload. aspx ?Id=25486\&tipo=ass $>$. Acesso em 27 de dezembro de 2017.

BRASIL,Lei Municipal de Curitiba n9460/1998. Disponível em: $<$ https:// leismunicipais.com.br/a/pr/c/curitiba/lei-ordinaria/1998/946/9460/leiordinaria-n-9460-1998-dispoe-sobre-a-regularizacao-de-parcelamentosdo-solo-para-fins-urbanos-implantados-irregularmente-no-municipiode-curitiba-ate-a-data-de-31-de-dezembro-de-1993-e-da-outrasprovidencias?q=9460>. Acesso em 27 de dezembro de 2017.

BRASIL,Plano Diretor de Curitiba. Lei Municipal $n^{0}$. 14.771/2015. Disponível em:< http://www.ippuc.org.br/visualizar.php?doc=http:// admsite2013.ippuc.org.br/arquivos/documentos/D310/D310_001_ BR.pdf $>$ Acesso em 20 de dezembro de 2017.

BRASIL,Plano Diretor de Curitiba. Lei Municipal $n^{0}$. 14.771/2015. Controle Ambiental e Desenvolvimento Sustentável. Análise de 
Desempenho 1970 a 2009. P.55 Disponível em::< http://www.ippuc. org.br/visualizar.php?doc=http://admsite2013.ippuc.org.br/arquivos/ documentos/D310/D310_001_BR.pdf> Acesso em 20 de dezembro de 2017.

BRASIL, Prefeitura Municipal de Curitiba.Plano Municipal de Habitação e Habitação de Interesse Social. 2008, p.77 a 84. Disponível em:<http:// www.ippuc.org.br/mostrarpagina.php?pagina=312> Acesso em 28 de dezembro de 2017.

BRASIL, Tribunal de Justiça do Paraná.Apelação em Ação Civil Pública

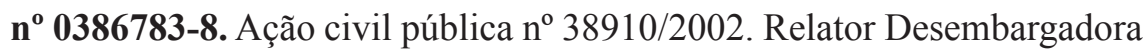
Rosene Arão de Cristo Pereira.

CAVALCANTI, Clóvis de Vasconcelos.Desenvolvimento e natureza: estudos para a sociedade sustentável. 2. ed. São Paulo: Cortez, 1998.

COMPANHIA DE HABITAÇÃO POPULAR DE CURITIBA- COHABCT.Relatório de gestão 2002/2004. Curitiba: COHAB/CT, 2004.

CUNHA, Luis Henrique; BRANQUINHO NUNES, Aldo Manoel. Proteção da natureza e conflitos ambientais em assentamentos rurais. Desenvolvimento e Meio Ambiente, n. 18, p. 27-38,jul./dez. 2008. Editora UFPR.

DUBOIS-MAURY, J.; CHALINE, C.Les risques urbains. Paris: Armand Colin, 2002.

FERNANDES,Edésio. Do código civil ao estatuto da cidade: algumas notas sobrea trajetória do direito urbanístico no Brasil. In: FERNANDES,Edésio; ALFONSIN, Betânia. Evolução do direito urbanístico brasileiro. Belo Horizonte: PUC Minas Virtual, 2006.

FERNANDES,Edésio. Estatuto da Cidade, mais de 10 anos depois: razão de descrença, ou razão de otimismo.Revista UFMG. Belo Horizonte, vol. 20, n. 1,jan./jul., 2013.

FREITAS, Vladimir Passos de.Matas ciliares. In: FREITAS, Vladimir Passos de.(Org.)Direito Ambiental em evolução. Curitiba: Juruá, 2005.

GOMES, Francisco Donizete.Direito fundamental social à moradia: legislação internacional, estrutura constitucional e plano 
infraconstitucional. Porto Alegre: UFRGS. Faculdade de Direito 2005.

GRAZIA, G.; QUEIROZ, L. L. et al. O desafio da sustentabilidade urbana. Rio de Janeiro: FASE/IBASE, 2001.(Série Cadernos Temáticos, n. 5).

HARVEY, David. A liberdade da cidade. In: MARICATO, Ermínia [et al.].Cidades rebeldes: passe livre e as manifestações que tomaram as ruas do Brasil. São Paulo:Boitempo: Carta Maior, 2013.

INSTITUTO DE PESQUISA E PLANEJAMENTO URBANO DE CURITIBA.Plano Municipal De Regularização Fundiária Em Áreas De Preservação Permanente. Curitiba 2007. P.151. Disponível em: $<$ http:// www.ippuc.org.br/visualizar.php?doc=http://admsite2013.ippuc.org. br/arquivos/documentos/D312/D312_006_BR.pdf >. Acesso em 28 de dezembro de 2017.

JORNAL GAZETA DO POVO,Quanto custa a regularização fundiária em Curitiba? 28.09.2016. Disponível em: $<$ http://www.gazetadopovo.com. br/vida-e-cidadania/futuro-das-cidades/quanto-custa-a-regularizacaofundiaria-em-curitiba-0d0d6y2ijg48zljwfvelyhqhg> Acesso em 10 de novembro de 2017.

KALIL, Ana Paula Maciel Costa; FERREIRA, HelineSivini. A dimensão socioambiental do estado de direito. Veredas do Direito, Belo Horizonte, v.14. n.28. p.329-359. Janeiro/Abril de 2017.

MAZINI, Pepita DurskiTramontini.O direito à informação ambiental. In: FREITAS, Vladimir Passos (Org.). Direito ambiental em revolução 1. Curitiba: Juruá, 2002.

MEIRINHO, Bruno Cesar Dechamps; ROCHA,Líbina da Silva; AULER, Mariana Marques.Regularização fundiária: política pública ou negócio? Como Curitiba propõe a regularização de assentamentos autoconstruídos. $\mathrm{O}$ mito do planejamento urbano democrático: reflexões a partir de Curitiba. Mobiliza Curitiba. Organização de Luana Xavier Pinto Coelho. - Curitiba: Terra de Direitos, 2015.

MENDONÇA, Francisco. Riscos, vulnerabilidade e abordagem socioambiental urbana: uma reflexão a partir da RMC e de Curitiba. Desenvolvimento e Meio Ambiente, n. 10, p. 139-148,jul./dez. 2004. Editora UFPR. 
MOBILIZA CURITIBA,Política Pública de moradia Popular. O mito do planejamento urbano democrático: reflexões a partir de Curitiba. Mobiliza Curitiba. Organização de Luana Xavier Pinto Coelho. - Curitiba: Terra de Direitos, 2015.

OBSERVATÓRIO DAS METRÓPOLES. Identificação dos espaços metropolitanos e construção de tipologias: relatório de atividade 1. [S.1.]: IPARDES, 2004. Projeto Análise das Regiões Metropolitanas do Brasil. Contrato Ministério das Cidades, FASE. Trabalho realizado por IPARDES, IPPUR, FASE. Disponível em: $<$ http://www.observatoriodasmetropoles. ufrj.br/produtos/produto_mc_1.pdf $>$. Acesso em 20 de dezembro de 2017.

ONU.Declaração Universal dos Direitos Humanos, 1948. Disponível em:<http://portal.mj.gov.br/sedh/ct/legis_intern/ddh_bib_inter_universal. $\mathrm{htm}>$. Acesso em 25 de novembro de 2017.

PEREIRA, Maurício.Depoimentos. O mito do planejamento urbano democrático: reflexões a partir de Curitiba. Mobiliza Curitiba. Organização de Luana Xavier Pinto Coelho. - Curitiba: Terra de Direitos, 2015.

RODRIGES,Giziane.Depoimentos. O mito do planejamento urbano democrático: reflexões a partir de Curitiba. Mobiliza Curitiba. Organização de Luana Xavier Pinto Coelho. - Curitiba: Terra de Direitos, 2015.

RODRIGUES, Arlete Moysés. Estatuto da Cidade: função social da cidade e da propriedade. Alguns aspectos sobre população urbana e espaço.Cadernos Metrópole, n. 12, $2^{\circ}$ sem., 2004.

RODRIGUES, E. R. CULlEN JR., L.; BELTRAME, T. P.; MOSCOGLIATO, A. V.; SILVA, I. C. Avaliação econômica de sistemas agroflorestais implantados para recuperação de reserva legal no Pontal do Paranapanema, São Paulo.Revista Árvore, v.31, n.5, p.941-948, ViçosaMG, 2007.

SANCHES, Jussara Romero Sanches; ARAUJO JUNIOR, Miguel Etinger de. Multidimensionalidade do direito à cidade no estatuto da cidade. Revista de DireitoUrbanístico, Cidade e Alteridade.e-ISSN: 2525989X. Brasília, v. 3, n. 1,Jan/Jun. 2017.

SANTOS JUNIOR, Orlando Alves dos; MÜLLER, Cristiano (orgs.).Direito Humano à Cidade. Coleção Cartilhas de Direitos Humanos, vol. VI, $1^{\text {a }}$ 
ed., Curitiba: Plataforma DhescaBrasil, 2008.

SANTOS, Hilma de Lourdes Santos.Depoimentos. O mito do planejamento urbano democrático: reflexões a partir de Curitiba. Mobiliza Curitiba. Organização de Luana Xavier Pinto Coelho. - Curitiba: Terra de Direitos, 2015 .

SARLET, Ingo Wolfgang. O Direito Fundamental à Moradia na Constituição: Algumas Anotações a Respeito de seu Contexto, Conteúdo e Possível Eficácia.Revista Brasileira de Direito Público- RBDP, Belo Horizonte, ano 1, n.02, p. 65-119,jul./set. 2003.

SILVA,Poliana Henriques da.O impacto do plano diretor do município de volta redonda na busca de uma sociedade cidadã.Revista de Direito Urbanístico, Cidade e Alteridade, e-ISSN: 2525-989X, Curitiba, v. 2, n. 2,Jul/Dez. 2016.

TERRA DE DIREITOS,Contratos falsos da COHAB-CT. 02/03/2013.

Disponível em:< http://terradedireitos.org.br/casos-emblematicos/ contratos-falsos-da-cohabct/11570>. Acesso em 30 de dezembro de 2017.

TONELLA, Celene. Políticas Urbanas no Brasil: marcos legais, sujeitos e instituições.Revista Sociedade e Estado. Volume 28 Número 1. Janeiro/ Abril 2013.

VALLE, Vanice Lírio do.Demandas derivadas e ampliação do núcleo essencial do direito a moradia: Deferência como critério judicial de solução. In: José Ribas Vieira; Margarida Maria Lacombe Camargo; Rogerio Barros Sganzerla.(Org.). Direitos fundamentais e jurisdição constitucional. 1ed.Belo Horizonte: Editora Fórum, 2016, v. 1.

Artigo recebido em: 23/02/2018. Artigo aceito em: 25/06/2018.

\section{Como citar este artigo (ABNT):}

FERRAZ, M. O. K.; PINTO, A. L. S. O.; BLANCHET, L. A. ASSENTAMENTOS IRREGULARES EM CURITIBA/PR: A PROTEÇÃO AO MEIO AMBIENTE E OS ENTRAVES PARA A REGULARIZAÇÃO DE MORADIAS. Veredas do Direito, Belo Horizonte, v. 15, n. 32, p. 167-199, mai./ago. 2018. Disponível em: <http:// www.domhelder.edu.br/revista/index.php/veredas/article/view/1251>. Acesso em: dia mês. ano. 